\title{
Protein Phosphorylation in Cancer: Role of Nitric Oxide Signaling Pathway
}

\author{
Xinran Liu ${ }^{1,2,+}$, Yiping Zhang ${ }^{1,2,+}$, Yijie Wang ${ }^{1,2,+}$, Meiwen Yang ${ }^{3,4}$, Fenfang Hong ${ }^{5, *}$ and Shulong Yang ${ }^{1,3, *(D)}$ \\ 1 Department of Physiology, College of Medicine, Nanchang University, Nanchang 330006, China; \\ liuxinran_sheila@163.com (X.L.); yipingzhang53@yeah.net (Y.Z.); yijiewyj0406@163.com (Y.W.) \\ 2 Queen Mary School, Nanchang University, Nanchang 330006, China \\ 3 Department of Physiology, Fuzhou Medical College, Fuzhou 344000, China; y18379441123@126.com \\ 4 Department of Nurse, Nanchang University Hospital, Nanchang 330006, China \\ 5 Experimental Center of Pathogen Biology, Nanchang University, Nanchang 330031, China \\ * Correspondence: hongfenfang@126.com (F.H.); slyang@ncu.edu.cn (S.Y.) \\ + Co-first author.
}

check for

updates

Citation: Liu, X.; Zhang, Y.; Wang, Y.; Yang, M.; Hong, F.; Yang, S. Protein Phosphorylation in Cancer: Role of Nitric Oxide Signaling Pathway. Biomolecules 2021, 11, 1009. https:// doi.org/10.3390/biom11071009

Academic Editor: Peter Coopman

Received: 17 May 2021

Accepted: 6 July 2021

Published: 10 July 2021

Publisher's Note: MDPI stays neutral with regard to jurisdictional claims in published maps and institutional affiliations.

Copyright: (c) 2021 by the authors. Licensee MDPI, Basel, Switzerland. This article is an open access article distributed under the terms and conditions of the Creative Commons Attribution (CC BY) license (https:// creativecommons.org/licenses/by/ $4.0 /)$.

\begin{abstract}
Nitric oxide (NO), a free radical, plays a critical role in a wide range of physiological and pathological processes. Due to its pleiotropic function, it has been widely investigated in various types of cancers and is strongly associated with cancer development. Mounting pieces of evidence show that NO regulates various cancer-related events, which mainly depends on phosphorylating the key proteins in several signaling pathways. However, phosphorylation of proteins modulated by NO signaling pathway may lead to different effects in different types of cancer, which is complex and remains unclear. Therefore, in this review, we focus on the effect of protein phosphorylation modulated by NO signaling pathway in different types of cancers including breast cancer, lung cancer, prostate cancer, colon cancer, gastric cancer, pancreatic cancer, ovarian cancer, and neuroblastoma. Phosphorylation of key proteins, including p38 MAPK, ERK, PI3K, STAT3, and p53, modified by NO in various signaling pathways affects different cancer-related processes including cell apoptosis, proliferation, angiogenesis, metastasis, and several cancer therapies. Our review links the NO signaling pathway to protein phosphorylation in cancer development and provides new insight into potential targets and cancer therapy.
\end{abstract}

Keywords: nitric oxide; cancer; protein phosphorylation; signaling pathways

\section{Introduction}

The development of the tumor is influenced by multiple factors including heredity and environment. In the genetic central dogma, genetic information is transmitted from DNA to mRNA, which is called transcription. Then, RNA is translated into protein, which will process by post-translational modifications (PTM) later on. Studies have shown that mRNA abundance in tissues is not completely consistent with protein abundance [1]. Therefore, the gene does not account for all the phenotypes. PTM is the process of covalent processing of a protein after translation by adding chemical groups to one or more amino acid residues, which can change the physicochemical properties of the protein, thereby influencing the spatial conformation and activity state of the protein, subcellular localization and protein interactions. More than 300 types of PTM are known, but only few have been studied, including phosphorylation, acetylation, ubiquitination, N-glycosylation, nitrification, propionylation, etc. [2].

Among them, protein phosphorylation is the most common and important in PTM. About $30 \%$ of the human proteome is phosphorylated, which is involved in almost all life processes of the cell, such as cell division, protein decomposition, signal transduction, gene expression regulation, and protein interaction [3]. However, when there are mutations at the site of protein phosphorylation, it may lead to the occurrence and development 
of a malignant tumor. Since the enzymes are proteins, the abnormal enzymes may lead to abnormal cell life activities and further lead to carcinogenesis [4]. Many phosphorylation pathways including MAPK, PI3K/Akt, tyrosine kinase, Cadherin-catenin complex, Cyclin-dependent kinase, NF-kappaB and IkappaB proteins, TGF- $\beta$ Signaling, etc. play an important role in cancer development [5].

Specifically, protein phosphorylation promotes the occurrence and development of cancer in the following aspects: inducing the cancer cell proliferation, inhibiting the cancer cell apoptosis, inducing cancer cells invasion and metastasis, inducing cancer cells angiogenesis and inducing cancer stem cells proliferation. Therefore, an in-depth understanding of the relevant mechanisms and signal pathways of protein phosphorylation disorders and related regulatory enzymes can help us to further understand the pathogenesis of cancer and screen tumor-related markers and target molecules, which is also of great significance to the research for potential targeted therapeutic antitumor drugs.

Nitric oxide (NO) is mainly oxidized from L-arginine by the catalyzation of nitric oxide synthase (NOS). As an intracellular signal, it functions in the cardiovascular, neural and immune systems. Depending on different NOS isoforms, NO exhibits different characteristics and functions. Neural NOS (nNOS) and endothelial NOS (eNOS) produce small amounts of $\mathrm{NO}$, which can act as a neurotransmitter, vasodilator, or assist in the release of insulin. While inducible NOS (iNOS) -induces large amounts of NO to fight against pathogens [6]. The effect of NO on cancer cells is dichotomous, which may depend on the type of cancer and the isoforms of NOS [7]. It is commonly believed that iNOS-induced NO promotes carcinogenesis and is associated with lower survival and chemoresistance [8]. However, this idea is still under debate until now. Some studies have also shown that iNOS and iNOS-induced NO act as cancer inhibitors in some cases [9].

Furthermore, the concentration and duration of NO exposure also influence its functions. Usually, NO regulates physiological pathways through the soluble-guanylyl-cyclase (sGC)-cGMP pathway and S-nitrosylation [9]. At a low concentration, along with NO derivatives such as nitrite and nitrate, NO may promote the chemoresistance and metastasis of cancer [10]. NO induces nitro-oxidative stress and interferes with the balance of redox, resulting in carcinogenesis [11]. In addition, NO production by cancer cells plays a role in activating signaling pathways involved in proliferation, angiogenesis, and metabolism [11,12]. While at a high concentration, accompanied by NO derivatives such as nitrite and nitrate, $\mathrm{NO}$ is more prone to upregulate cancer cell apoptosis and has a cytotoxic function $[10,13]$.

The effect of NO-related pathway on cancer is the result of many pathways being intertwined, coordinated and even antagonistic. The activity of mitogen-activated protein kinases (MAPKs), phosphoinositide 3-kinase (PI3K)/Akt, TNF $\alpha / \mathrm{NF}-\mathrm{kB}$, IL6/STAT3, and other pathways, along with many pathway-related proteins, may induce a dual effect of $\mathrm{NO}$ on cancer cells (Figure 1). The activation or inhibition of these signaling pathways is correlated with the phosphorylation and dephosphorylation of related proteins and enzymes in cancer cells (Figure 1, Table A1 Appendix A).

Mitogen-activated protein kinases (MAPKs) are a family of kinases that transmit the signal from the cell membrane to the nucleus, involved in controlling cell proliferation, differentiation, death, and even malignancies and pathogenesis of tumor. There are three major signaling pathways in MAPK cascades. Firstly, the extracellular signal-regulated kinase (ERK)-1/2 targets both membrane proteins and transcription factors, which may function in cancer cell proliferation and survival. The second pathway is cJun $\mathrm{NH}_{2}$-terminal kinases (JNK), which play a role in cell apoptosis and oncogenesis. The third one is the p38 MAPK pathway, with its double roles in cancer including inducing and inhibiting leukemia cell proliferation [14].

$\mathrm{PI} 3 \mathrm{~K} / \mathrm{Akt} / \mathrm{mTOR}$ signaling pathway mutation is common in various cancer types. PI3K is one of the phosphatidylinositol kinases. When binding with growth factor receptors such as EGFR, PI3K can induce the conformational change of the Akt protein and activate or inhibit downstream substrate via phosphorylation, thus regulating cell proliferation, 
differentiation, apoptosis, and migration. Akt can also activate IKK and has crosstalk with NF-kB. mTOR is the downstream target of PI3K/Akt, whose downstream transcriptional factors include $\mathrm{HIF} 1 \alpha$, c-Myc, and FoxO [15].

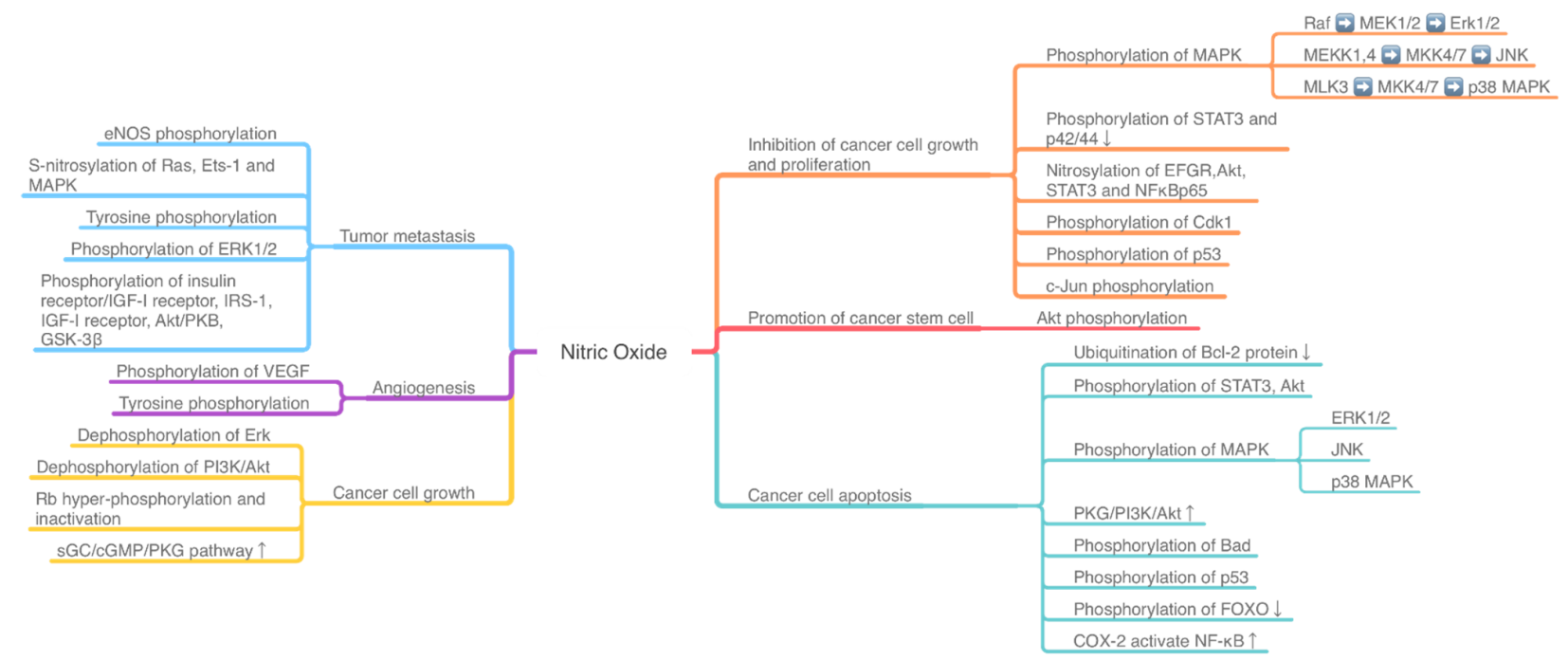

Figure 1. The NO-induced phosphorylation pathway influences the tumor development and death. ERK: extracellular signalregulated kinase; PI3K: phosphoinositide 3-kinase; MAPK: mitogen-activated protein kinases; MEK: MAPK kinase; MKK: MAPK kinase kinase; ETS-1: E26 avian erythroblastosis virus transcription factor-1; VEGF: vascular endothelial-derived growth factor; JNK: Jun NH2-terminal kinase; Rb: retinoblastoma protein; FOXO: Forkhead box-O; IGF: insulin/insulin-like growth factor; GSK-3 $\beta$ : glycogen synthase kinase- $3 \beta$.

\section{Protein Phosphorylation in Different Cancer Induced by NO}

In this section, we review the effect of NO signaling pathway to protein phosphorylation in different types of cancers including breast cancer, lung cancer, prostate cancer, colon cancer, gastric cancer, pancreatic cancer, ovarian cancer, and neuroblastoma.

\subsection{Breast Cancer}

With its increasing morbidity, breast cancer has become one of the most common malignant tumors in women, and also the seventh most common cancer in China. Many studies have indicated that there is a correlation between NO expression and breast cancer $[16,17]$. Different concentrations of NO have the functions of both inducing and inhibiting cancer development depending on the phosphorylation of $\mathrm{NO}$ downstream and upstream regulators. Generally, a low concentration of NO promotes the development of breast cancer by inducing cancer cell growth, metastasis, Epithelial-Mesenchymal Transition (EMT), angiogenesis, invasion, and migration. While a higher concentration of NO inhibits cancer cell growth and facilitates cancer cell apoptosis (Figure 2).

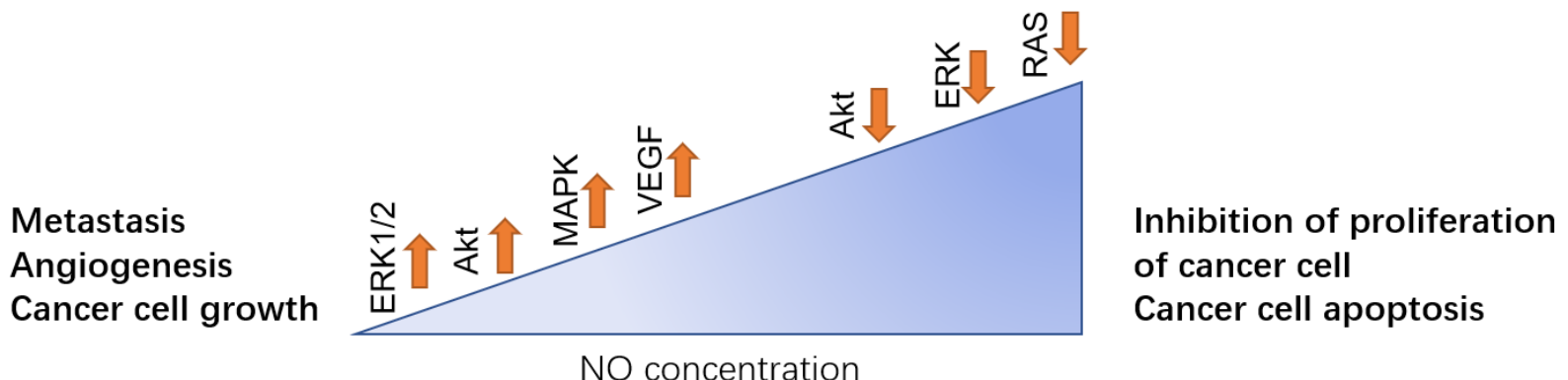

Figure 2. In breast cancer, different NO concentration levels play the opposite role. Low level of NO can facilitate the metastasis to other site of body such as lung, angiogenesis of the tumor and promote the cancer cell growth, which is mainly regulated by activation of ERK1/2, Akt, MAPK, and VEGF. While in high concentration, NO can downregulate those pathways, thus inhibiting the proliferation of the cancer cell and inducing cell apoptosis. 
Sen $S$ et al., found that tumor cell growth and proliferation are induced by mitochondrialassociated NOS, which keeps Akt and ERK1/2 in a phosphorylated state [18]. Moreover, Prueitt et al., found that phosphorylation of Akt has a strong correlation with NOS2, which is a synthase of NO [19]. Later, Ridnour LA et al., conducted a further study, which suggested that NO induces the phosphorylation of Akt in human breast cancer cell [20]. S-nitrosylation is one of the PTMs that is mediated by NO. Covalent NO is bound to the thiol side chain of a cysteine residue. It is reported that a high level of NO leads to activation of S-nitrosylation in breast cancer. S-nitrosylation of Ras contributes to the activation of Ets-1, which depends on the phosphorylation of MAPK and causing the metastasis of cancer [21]. Moreover, low production of NO was related to a decreased phosphorylation of eNOS, which is an indicator of the metastasis of breast cancer to other sites of the body at the early stage [19]. When cancer cells reach the site of metastasis, they experience MET (mesenchymal epithelial transition). In these cells, overconcentration of $\mathrm{NO}$ is prevalent [22]. It is reported that in the murine breast cancer cell line, glucocorticoids can induce angiogenesis through vascular endothelial-derived growth factor (VEGF) by increasing NO signaling. Also, it indicated that DNA damage and repair may be related to the phosphorylation of $\gamma-\mathrm{H} 2 \mathrm{AX}$ foci and RAD51 foci, which is induced by NO [23]. However, a high concentration of NO inhibits the growth of breast cancer. Human breast cancer cell apoptosis is induced by NO-induced MKP-1 followed by dephosphorylation of ERK, which then leads to dephosphorylation of Akt [24]. Moreover, the upregulation of the Raf/MEK/ERK and PI-3 kinase/Akt pathways of NO are mediated by RAS. Inactivation of RAS can weaken the function of NO [25].

\subsection{Lung Cancer}

With the worsening air pollution and an increasing number of smokers, the morbidity and mortality of lung cancer have ranked first place in all kinds of cancer. At the same time, lung is also a main metastasis site for other tumors such as colon cancer and breast cancer [26]. Many studies have shown that the phosphorylation of NO downstream signal pathway is correlated to the lung cancer cell proliferation, metastasis, angiogenesis, and cancer stem cell. Pamela L. Rice et al., found that NO promotes MEK1/2 phosphorylation, which induces tumor proliferation and growth in lung cancer [27]. Also, NOS overproduced NO can lead to tyrosine phosphorylation and p53 gene accumulation in the human liver epithelial cells [28]. iNOS induced NO can promote angiogenesis in lung cancer. In iNOS knockout mice, vascular endothelial growth factor decreased [29]. Furthermore, NOSinduced NO may exert its effects by influencing tyrosine phosphorylation of proteins and matrix metalloproteinase (MMP) expression in the sprouting tips of nascent capillaries [30]. The cancer stem cell is an important factor in the occurrence and development of malignant tumors. NO can increase cancer stem cell and stemness related protein in human lung cancer. NO promotes Akt-dependent phosphorylation of Caveolin-1 at tyrosine 14 and disrupts the Cav-1: Oct4 complex, then promotes the CSC-regulatory activity [31]. iNOS is a downstream mediator of activated Src kinase in lung cancer, which is an important factor of cell proliferation and metastasis in cancer. The study showed that iNOS is phosphorylated on a tyrosine residue by Src kinase in human alveolar type II epithelium-like lung carcinoma cell line. Therefore, inhibition of Src can be a promising therapy at the late stage of lung cancer [32]. Moreover, NO can increase cell death resistance in the cisplatin-treated lung cancer cell. A study showed that NO can nitrosylate the Bcl-2 protein and inhibit its ubiquitination, which reverses the anti-tumor function of cisplatin [33].

\subsection{Prostate Cancer}

In the study of prostate cancer to chemotherapy under hypoxia, PC-3 prostate cancer cells were treated with NO-sulindac under hypoxic conditions in vitro. A reduced ability of tumor cells to adapt to hypoxia and suppressed expression of hypoxia-inducible factor- $1 \alpha$ $(\mathrm{HIF}-1 \alpha)$ was observed under NO-sulindac treatment [34]. HIF-1 $\alpha$ is a transcription factor that regulates oxygen homeostasis and is thought to be related with tumor progression, 
angiogenesis, metastasis, and resistance [35], which may be responsible for chemoresistance under hypoxia [34]. The NO-sulindac can inhibit invasion and increase survival rate through suppressing the activity of hypoxia response element (HRE) promoter and inhibiting HIF-1 $\alpha$ translocation via inhibiting Akt phosphorylation under hypoxia [34]. Thus, it can be a therapeutic agent for the treatment of prostate cancer in hypoxic conditions. However, in addition to the suppression of cancer, NO may also have the opposite effect. It had been mentioned by Baltaci $S$ et al., that iNOS-induced NO played a facilitating role in the progression of prostatic tumorigenesis. Compared to the benign prostate tumor, iNOS expression was higher in prostatic carcinomas, and this could also be used for immunohistochemistry or biological function study of prostate cancers [36].

\subsection{Colon Cancer}

NO can suppress colon cancer cell growth by inhibiting the cell cycle. NO-aspirin (NO-ASA) as a more potential anticancer agent than aspirin, can modulate the phase transition proteins to arrest the tumor cell cycle at the G2/M phase in colon, pancreas, and breast cancer.

It increases Cdk1 phosphorylation while preventing dephosphorylation of Thr14 and Thr15 residues of Cdk1 by reducing the level of cdc25 [37]. Furthermore, NO-ASA inducedoxidative stress disturbs cyclin D at Cys285, which plays a role in the phosphorylation of Thr286 and/or Thr288, resulting in degradation of cyclin D. The arrestment of cell cycle is also enhanced by the upregulating of reactive oxygen species (ROS) production, which can interfere with the cell cycle through oxidizing/reducing cysteine residues on regulatory factors $[37,38]$.

Besides, NO-ASA also interacts with MAPK activation to inhibit colon cancer cell growth. By regulating the MAPK cascades, it stimulates the phosphorylation of p38 MAP kinases and JNK, which further phosphorylate the cJun and activate transcription factor 2 (ATF-2). The effects of NO-ASA at low concentrations on the phosphorylation of ERK-1/2 and Akt are not significant. However, in the presence of high concentrations of NO-ASA $(100 \mu \mathrm{M})$, phosphorylated ERK2 is significantly increased, while phosphorylation of Akt was shown to be inhibited for a certain period [14].

In addition to the above-mentioned effects, NO can inhibit the cell cycle and cause apoptosis in colon cancer cells by phosphorylating serine residues of p53 [39,40]. Activation of p53 can upregulate p21 expression and ultimately lead to cell cycle arrest and cell apoptosis [40]. The overexpression of iNOS enhances the activation of p53 by radiation therapy, which also demonstrates that $\mathrm{NO}$ acts as an apoptotic agent in cancer cells through the phosphorylation of p53 [40].

Actually, NO is prone to see dual effects in many pathophysiological activities. Its biological functions are related to the microenvironment concentration, cell susceptibility, and nitric oxide synthase isoforms. Increased levels of NOS expression have been seen to accompany the development of colon and pancreatic cancers. The auguring NO can interact with oncoproteins and signaling pathways that related to tumor progression [41].

Retinoblastoma protein $(\mathrm{Rb})$ is inactivated by iNOS-induced NO in colitis. With a low concentration, NO directs multiple pathways including sGC/cGMP pathway, PI3K/AKT and MAPK pathway to synergistically engage in $\mathrm{Rb}$ hyperphosphorylation and prevent $\mathrm{pRb}$-E2F1 pathway-induced apoptosis [42]. Although there is no clear point to the relationship between pRB hyperphosphorylation and colon cancer, it can be speculated that its role in colon cancer development may through a chronic inflammation-related carcinogenesis mechanism.

Furthermore, iNOS-induced NO is confirmed to play an important role in the metastasis, invasion and angiogenesis of colon cancer. NO-induced phosphorylation of ERK-1/2 peaks after $2 \mathrm{~h}$ in colon adenocarcinoma cell WiDr. Functioning through the NO-cGMPPKG-ERK1/2 pathway and nuclear translocation of AP-1, NO can upregulate MMP-2/9 expression and induce translocation of Fos-related antigen-1 (Fra-1) and Fos-related antigen- 
2 (Fra-2) [43]. MMP induce proteolysis and disrupts intercellular connections, therefore the upregulation of MMP can lead to metastasis and invasion of cancer cells.

\subsection{Gastric Cancer}

In gastric cancer cells, NO mainly impacts cell proliferation through regulating protein phosphorylation in several signaling pathways. Evidence obtained from the BGC-823 gastric cancer cell line shows that exposure to SNP at various concentration for $24 \mathrm{~h}$ inhibits the cell proliferation and Akt phosphorylation, suggesting that Akt may participate in NO-induced anti-proliferation in gastric cancer [44]. Moreover, type II cGMP-dependent protein kinase (PKG II) may also play an essential role in regulating cell proliferation. Xiaoyuan $\mathrm{Y}$ et al., increased the expression of PKG II by infecting AGS gastric cancer cell line with an adenoviral construct encoding PKG II cDNA (Ad-PKG II) and observed the inhibition of AGS cell proliferation induced by SNP. In addition, they also observed the significant inhibition of EGFR and ERK phosphorylation only in AGS cells that express a high level of PKG II [45]. Based on these results, it is indicated that SNP may inhibit the gastric cancer cell proliferation through activating PKG II to inhibit the EGF-induced EGFR phosphorylation, which in turn decreases the phosphorylation of ERK.

\subsection{Pancreatic Cancer}

Similar to colon cancer, $\mathrm{NO}$ has a dual function in the development of pancreatic cancer. NO leads to protective or anti-cancer cells effects exhibiting a profile associated with iNOS expression, which mainly induces a large amount of $\mathrm{NO}$ to respond to the stimulations.

In a study of pancreatic ductal adenocarcinoma (PDAC), high expression of iNOS was associated with lower survival rates of PDAC patients. iNOS/NO signaling can phosphorylate FoxO (Forkhead box-O) and inactivate it through the activation of ERK and PI3K/AKT signaling [46], resulting in impaired functions of cell cycle arrest, DNA repair, and apoptosis [47]. In addition, pancreatic cancer cells from iNOS-deficient mice exhibit diminished migration and invasion, which may be attributed to the lack of NO-induced activation of c-Src and impairment of E-cadherin junctions between cancer cells [46].

As stated earlier, there is a duality of action of NO. Kong G et al., concluded from a study of seventy-two pancreatic cancer tissue specimens that iNOS played a role in causing cancer cell apoptosis [48]. Beyond that, a previous study found the axon guidance factor netrin-1 upregulated NO production to activate protein phosphatase 2A (PP2A) phosphatase and decrease c-Jun phosphorylation. The enhancement of PP2A activity can suppress integrin $\beta 4$ expression through damaging the MEK/ERK pathway [49]. The impairment of the MEK/ERK/c-Jun pathway inhibits the growth of PDAC cells in vivo, which means NO plays an anti-cancer role in this mechanism.

In addition, the anti-cancer effect of NO is also reflected in the inhibition of proliferation and invasion of pancreatic cancer cells. In a study of investigating the effect of $\mathrm{NO}$ on the expression of insulin receptor substrate (IRS)-1 and insulin/insulin-like growth factor (IGF)-I in pancreatic cancer MIAPaCa-2 cells, it was found that NO donor reduced the expression of IRS-1, which is related to the stimulation of growth signaling pathway and cancer proliferation in pancreatic cancer [50,51]. Besides, it suppressed the phosphorylation of Akt/PKB and glycogen synthase kinase-3 $\beta$ (GSK-3 $\beta$ ) induced by inhibition of insulin/IGF-I. This was confirmed by a selective iNOS inhibitor $1400 \mathrm{~W}$, revealing the function of iNOS/NO in insulin/IGF-I signaling. However, meanwhile, NO also increases phosphorylation of ERK-1/2, leading to cell survival, which seems to contradict its anticancer effects [51].

The outcome of NO biological functions is the result of a combination of multiple factors and multiple pathways. Thus, Sugita $\mathrm{H}$ et al., suggested that the inhibitory effect of $\mathrm{NO}$ on the proliferation and invasion of cancer cells in their experiment may have been balanced by the phase opposition of the PI3K-Akt and Ras-ERK pathways [51]. 


\subsection{Ovarian Cancer}

Ovarian cancer is the fifth leading cause of death related to cancers in female and the most fatal type among all female reproductive cancers [52]. Mounting studies show that NO signaling pathway can impact the protein phosphorylation in ovarian cancer, which may play a role in cell apoptosis, proliferation, and migration.

STAT3, one of the key molecules involved in cell proliferation and survival, is constitutively active in tumor cells without tyrosine receptor kinases. It contains the transcriptional regulatory activity and regulates the expression of antiapoptotic genes and proliferation regulatory genes [53]. Evidence obtained from SK-OV-3 and OVCAR-3 ovarian cancer cell lines showed that high level of NO donors, including spermine nitric oxide complex hydrate (SPER/NO) and diethylenetriamine nitric oxide adduct (DETA/NO), induced apoptosis of both ovarian cancer cell lines accompanied with decreasing of STAT3 and Akt protein phosphorylation. Based on the results, this research suggested that NO donor could induce ovarian cancer cell apoptosis through inhibiting STAT3 and Akt phosphorylation, which was confirmed by incubating ovarian cancer cells with selective inhibitors of STAT3 and Akt protein [54]. However, NO also induces anti-apoptosis of ovarian cancer cells through modulating STAT3 phosphorylation. There is a consensus that NO contains pleiotropic biological activity depending on its concentration in the experimental condition. Therefore, the type of NO donor, its half-life, and type of ovarian cancer cell line can impact the role of NO in ovarian cancer cells. S-nitroso-N-acetylpenicillamine (SNAP), an NO donor, can rescue the inhibition of STAT3 phosphorylation induced by a certain antitumor drug to prevent apoptosis of human ovarian cancer OVCAR3 and SKOV3 cells at low concentration [55]. Survivin, highly expressed in tumor cells, acts as a major cytoprotective factor and regulates the apoptosis of ovarian cancer cells [56]. It is reported that NO can impact the expression of survivin through modifying the phosphorylation of upstream proteins to regulate the cell apoptosis in OVCAR3 and SKOV3 human ovarian cancer cell lines, depending on the concentration of NO. High concentration of NO inhibits the expression of survivin by increasing the phosphorylation of p38 MAPK to induce the ovarian cancer cell apoptosis, which is abrogated by pretreatment of p38 MAPK inhibitor [57]. However, low concentration of NO prevents drug-induced apoptosis of ovarian cancer cells through a different signaling pathway. Low amounts of iNOS expressed in ovarian cancer cells stimulate the phosphorylation of PI3K/Akt and subsequently promote the expression of survivin. The results are further confirmed by treating ovarian cancer cells with PI3K/Akt-inhibitor, which reverses the induction of survivin and enhances cell apoptosis [57]. In addition, $\mathrm{NO}$ can regulate cell apoptosis through a cGMP-dependent signaling pathway. Research demonstrates that $1 \mathrm{H}-[1,2,4]$ oxadiazo-lo[4,3-a]quinoxalin-1-one (ODQ), an inhibitor of sGC, stimulates the phosphorylation of p53 and then induces cell apoptosis in OV2008 human ovarian cancer cell line. Based on this research, it is indicated that the NO signaling pathway may be associated with the regulation of p53 phosphorylation, resulting in cell apoptosis [58].

Except for affecting cell apoptosis, NO signaling pathway also regulates cell proliferation via modulating protein phosphorylation in ovarian cancer. Evidence shows that S-nitrosoglutathione (GSNO), another NO donor releasing NO slowly, inhibits the cell proliferation in chemoresistant ovarian cancer cell lines. GSNO attenuates STAT3 and Akt phosphorylation induced by growth factor and reduces the basal level of their phosphorylation forms [59], suggesting that GSNO may inhibit cell proliferation by regulating the growth factor-induced signaling pathway in ovarian cancer cells. Moreover, Shailendra Giri et al., demonstrated that GSNO may inhibit the phosphorylation of key ovarian cancer-promoting protein through nitrosylation, indicating the potential therapeutic role of nitrosylating agents [59]. Furthermore, sepiapterin, the precursor of a critical cofactor for nitric oxide synthase, can stimulate cell proliferation and migration in SKOV3 human ovarian cancer cell line, accompanied by activation of ERK, Akt and p70S6K. These effects induced by sepiapterin are blocked by NO synthase inhibitor, suggesting that NO may 
affect sepiapterin-induced cell proliferation through modulating the phosphorylation of proteins in the mitogenic signaling pathway [60].

\subsection{Neuroblastoma}

Accumulating research shows that NO mainly regulates cell apoptosis in neuroblastoma through modulating the phosphorylation of key proteins in several signaling pathways. JNK, as a key factor in cell signaling, regulates a wide range of biological activities, including apoptosis through phosphorylating the downstream protein c-Jun on Ser-63 and Ser-73 [61]. Mounting evidence shows that in neuroblastoma, high concentration of $\mathrm{NO}$ can activate JNK and then increase the phosphorylation of c-Jun indirectly, resulting in cell apoptosis. In this process, Lei L et al., indicated that NO-induced activation of JNK may only phosphorylate c-Jun on Ser-63 in human neuroblastoma cell lines [62]. Moreover, NO may also impact the phosphorylation of ERK and p38 MAPK to induce cell apoptosis in neuroblastoma. Evidence obtained from the SH-EP1 human neuroblastoma cell line shows that high concentration of SNP stimulates the phosphorylation of ERK and p38 MAPK, contributing to cell apoptosis. SNP-induced cell apoptosis can be reversed by ERK and p38 MAPK inhibitor, respectively [63]. Tetsuaki $\mathrm{N}$ et al., confirmed the hypothesis in a different neuroblastoma cell line, the SH-SY5Y cell line [64]. Combined with the results mentioned before, they found that SNP also induced the increase of intracellular $\mathrm{Ca}^{2+}$ concentration significantly and all these effects induced by SNP were abolished after treating the $\mathrm{Na}^{+} / \mathrm{Ca}^{2+}$ exchanger (NCX) inhibitor, suggesting that $\mathrm{Ca}^{2+}$ influx via NCX may mediate the SNP-induced protein phosphorylation. In addition, the increase of intracellular $\mathrm{Ca}^{2+}$ level induced by SNP can be inhibited by a cGMP-dependent protein kinase (PKG) inhibitor, resulting in the inhibition of SNP-induced cell apoptosis [64]. Taken together, these results indicate that NO may activate NCX via the cGMP/PKG signaling pathway to promote the influx of $\mathrm{Ca}^{2+}$, resulting in stimulating cell apoptosis through phosphorylation of ERK and p38 MAPK.

Due to the pleiotropic function of NO, it can also protect neuroblastoma cells against apoptosis through modulating a different signaling pathway. There is a consensus that PI3K/Akt pathway is essential to cell survival [65]. Evidence shows that SNP promotes cell survival in neuroblastoma treated with $\mathrm{H}_{2} \mathrm{O}_{2}$, accompanied by the increase of Akt phosphorylation. These effects induced by SNP can be reversed by the inhibitor of PI3K, suggesting that SNP may modulate the PI3K/Akt signaling pathway to prevent the apoptosis of neuroblastoma cell [66]. Additionally, in SNP-treated neuroblastoma cell line, the phosphorylation of Bad and its interaction with neural cell type protein 14-3-3 $\beta$ increase significantly, suggesting that SNP may induce the interaction between p-Bad and $14-3-3 \beta$ to block the cell apoptosis cascade. Based on these results, it is predicted that $\mathrm{NO} / \mathrm{cGMP} / \mathrm{PKG}$ may be involved in SNP-induced anti-apoptosis of neuroblastoma to regulate the phosphorylation of Akt and Bad. This hypothesis has been confirmed by treating neuroblastoma cells with sGC and PKG inhibitors respectively, resulting in the inhibition of these effects induced by SNP [66].

\section{The Therapeutic Effect of Nitric Oxide}

Nitric oxide was first discovered by Ferid Murad for its role in promoting cardiovascular dilation. In oncology, NO has been discussed as an oncogene in the past. However, recently, it was discovered that the proper concentration of NO has a role in the cancer cell cycle, death, metastasis, migration, and angiogenesis $[67,68]$. Therefore, NO and its donor drugs have been increasingly used in cancer chemoprophylaxis, radiotherapy, chemotherapy, and immunotherapy [69]. At low concentration, NO includes in the activation and phosphorylation of ERKs, Akt/mTOR, STAT and Ras signal pathway to enhance angiogenesis and metastasis and stimulate cancer cell progression. However, as an effective vasodilator, $\mathrm{NO}$, is also used in delivering the antitumor drug. In this situation, narrow vessels around the tumor are dilated and blood flow increases, thus the drug can efficiently function [70]. While at higher concentration, NO intends to depress tumor development 
by inducing cell apoptosis, sensitizing tumors to radiotherapy, reversing resistance to chemotherapy, and declining the angiogenic and metastatic cascades [9]. Also, the study showed that ERK-P, Akt-P, and p53 are correlated with a high concentration of NO, thus inhibiting cancer progression [13].

NO donor commonly found in cancer including organic nitrates, sodium nitroprusside, S-nitrosothiols, sydnonimines, DETA/NO, and JS-K [71]. Organic nitrates, sodium nitroprusside, and S-nitrosothiols have the antitumor function in radiosensitization during therapy. Sydnonimines induce cell injury by DNA damage, increasing protein nitration and decreasing mitochondrial respiration chain. Both organic nitrates and DETA/NO can reduce doxorubicin resistance. A study showed that a low level of DETA/NO can reverse the resistance of human breast cancer to chemotherapeutic agents 5-FU and doxorubicin [72]. Moreover, JS-K can specifically target glutathione (GSH) which is overexpressed in cancer cells [73]. SNOHSA, a NO donor significantly inhibited hypoxia-induced autophagy by inhibiting the phosphorylation of JNK1 and the expression of its downstream molecule Beclin1 in the cancer cell, thereby inhibiting drug resistance [74]. Therefore, the combination of NO donor and gas therapy with other anti-cancer therapies has achieved further tumor suppression including reducing resistance to oncology drugs. It is indicated that NO can reduce the expression of P-glycoprotein and ATP-binding cassette transporters, thus decreasing the multidrug resistance of tumor therapy. NO stimulated nanosystem can promote the accumulation of doxorubicin in blood and reduce its resistance [75,76]. To conclude, Since NO plays an important role in tumor development and inhibition, further researches on its related drug and signal pathways are necessary. Those exogenous deliveries of NO drugs have different inhibitory mechanisms inducing DNA damage, radiosensitization of cancer cell, and reducing multidrug resistance. However, since more NO donor drugs exhibit experiment on the animal instead of the human body, More clinical experiments on the tumor of various organs should be completed in the future.

\section{Conclusions}

This review briefly describes the effect of NO on pathways or protein phosphorylation processes in eight cancers, which cause either positive or negative outcomes.

Based on the above, it is clear that NO affects cell growth, apoptosis, angiogenesis, cancer invasion, and metastasis mainly through influencing the phosphorylation status of phase transition proteins, the PI3K/Akt pathway, and MAPK pathway, as well as some downstream proteins and transcription factors (Figure 3). Compared to the two-fold effect of NO on anti-cancer effects, which may be related to the NO concentration and its duration of action, $\mathrm{NO}$ induced by iNOS is prone to show a more complex regulation of cancer development. iNOS-induced NO have cytotoxic and cytostatic functions on tumor cells [10], but is also involved in cancer development and progression. Perhaps more research is needed in the future to determine the exact role of iNOS in cancer development and whether this role is tumor specific.

Many NO-releasing compounds are produced; however, more in-depth research is still needed. Not only does the drug itself need to be stable and have few side effects, but it also needs to avoid the cancer-promoting effects of $\mathrm{NO}$ and extend its anti-cancer benefits as much as possible. For example, NO-sulindac, as described above, can reduce the tolerance of prostate cancer to chemotherapy under hypoxic conditions by inhibiting HIF- $1 \alpha$, which can be used to exploit a better treatment by increasing the sensitivity of hypoxic cells to chemotherapy and radiation therapy [34,77]. In addition, novel NO-releasing biomaterials for tumor-targeted therapy are designed for a better control of NO delivery to overcoming drug resistance in chemotherapy [78].

The introduction of $\mathrm{NO}$ and NO synthetic drugs may be a new direction for cancer treatments, or they can be used as an adjunct to reduce therapy resistance, but more research is urgently needed to achieve their clinical application. 


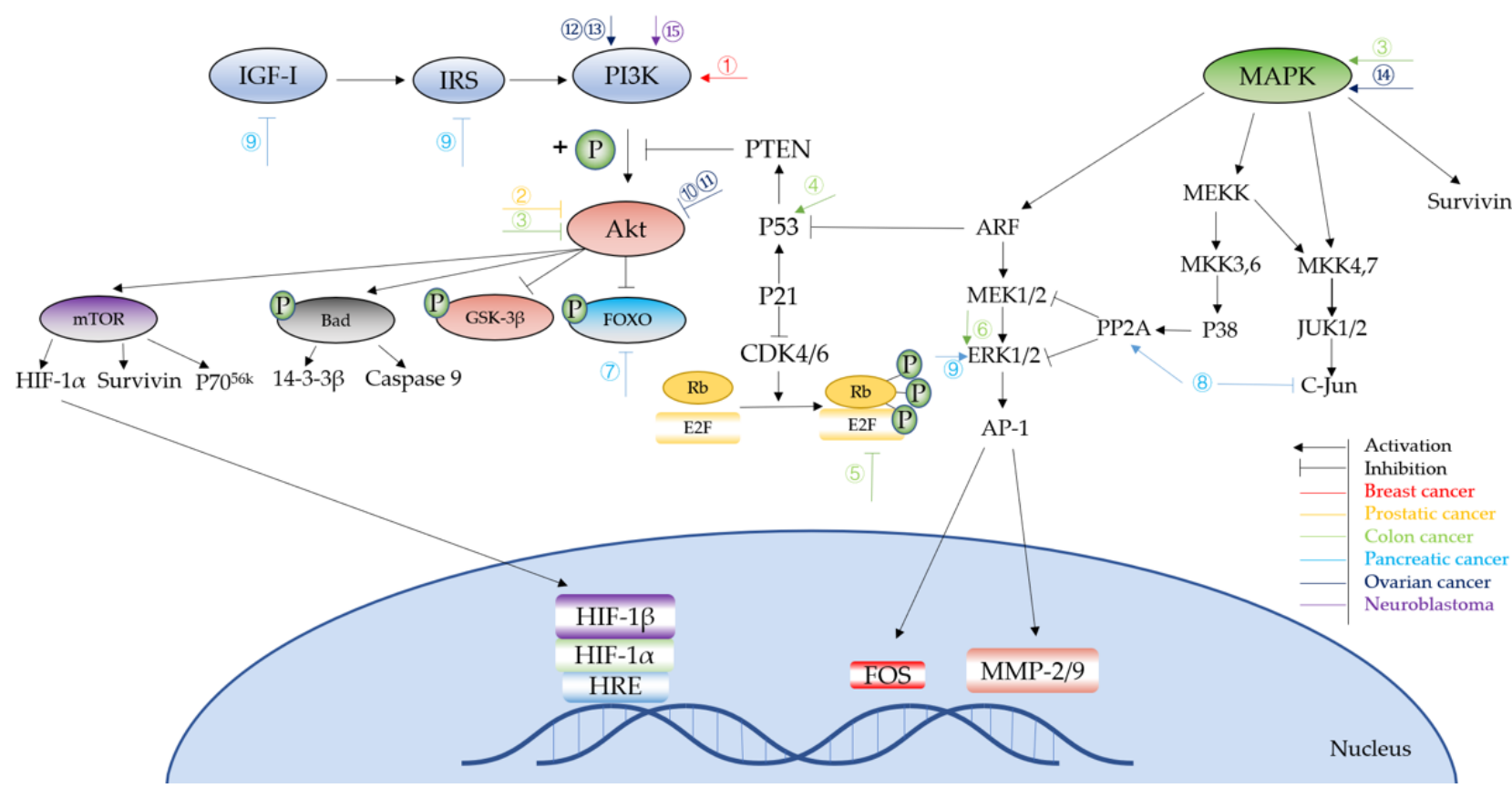

Figure 3. Signaling pathways of NO in different cancer types. (1) Pretreatment: NOS2 Result: block apoptosis. (2) Pretreatment: NO-sulindac Result: inhibit invasion, increase survival and induce ability to adapt to hypoxia. (3)Pretreatment: NO-ASA Result: inhibit cancer growth. (4)Pretreatment: NO Result: inhibit cell cycle and apoptosis. (5) Pretreatment: iNOS-induced NO Result: colitis and anti-apoptosis. (6)Pretreatment: NO Result: metastasis and invasion. (7)Pretreatment: iNOS/NO Result: impaired cell cycle arrest, DNA repair and apoptosis. 8Pretreatment: Axon guidance factor retrin-1 upregulate NO Result: anti-cancer. (9Pretreatment: NO donor Result: inhibit proliferation and invasion. (10Pretreatment: GSNO Result: inhibit cell proliferation. 11Pretreatment: SPER/NO, DETA/NO Result: apoptosis. (12) Pretreatment: Sepiapterin Result: cell proliferation. ${ }^{13}$ Pretreatment: iNOS Result: cytoprotection. (14)Pretreatment: NO Result: apoptosis. (15)Pretreatment: SNP Result: apoptosis.

Author Contributions: X.L., Y.Z. and Y.W. contributed equally to this work, they wrote the paper and did data curation; M.-w.Y. revised the paper; F.H., and S.Y. contributed equally to this work, they are responsible for the idea, fund, and revision. All authors have read and agreed to the published version of the manuscript.

Funding: This research was funded by the National Natural Science Foundation of China, grant number 81660751, 81660151, 82060661.

Institutional Review Board Statement: Not applicable.

Informed Consent Statement: Not applicable.

Data Availability Statement: Not applicable.

Conflicts of Interest: The authors declare no conflict of interest.

\section{Appendix A}

Table A1. The impact of the NO pathway on partial pathways and proteins in different types of cancer.

\begin{tabular}{|c|c|c|c|c|c|c|}
\hline Cancer Types & Experimental Cells & $\begin{array}{c}\text { Signaling } \\
\text { Pathway/Protein }\end{array}$ & Pre-Treatment & $\begin{array}{c}\text { NO/iNOS/eNOS } \\
\text { Level }\end{array}$ & Result & Ref. \\
\hline Colon cancer & $\begin{array}{l}\text { HT-29 Colon Cancer } \\
\text { Cell }\end{array}$ & $\begin{array}{c}\uparrow \text { Phosphorylation of JNK, } \\
\text { p38 MAP kinases, cJun } \\
\text { and ATF-2; Activates AP-1 } \\
\text { Complex }\end{array}$ & NO-aspirin & $\mathrm{NO} \uparrow$ & $\begin{array}{l}\text { Inhibit cancer } \\
\text { cell growth }\end{array}$ & [14] \\
\hline Breast cancer & $\begin{array}{c}\text { ZR-75-30, BT-474, } \\
\text { MCF-12F }\end{array}$ & $\begin{array}{l}\text { Akt and ERK1/2 } \\
\text { phosphorylation }\end{array}$ & $\begin{array}{c}\text { Inhibitor of NO } \\
\text { synthesis }\end{array}$ & $\operatorname{NOS} \uparrow$ & $\begin{array}{l}\text { Tumor cell } \\
\text { growth and } \\
\text { proliferation }\end{array}$ & [18] \\
\hline Breast cancer & $\begin{array}{l}4 \mathrm{~T} 1 \text { murine breast } \\
\text { cancer cells }\end{array}$ & Akt phosphorylation & $\begin{array}{l}4 \mathrm{~T} 1 \text { cancer cell } \\
\text { inoculation }\end{array}$ & NOS $2 \uparrow$ & $\begin{array}{l}\text { Tumor cell } \\
\text { growth and } \\
\text { proliferation }\end{array}$ & [19] \\
\hline
\end{tabular}


Table A1. Cont.

\begin{tabular}{|c|c|c|c|c|c|c|}
\hline Cancer Types & Experimental Cells & $\begin{array}{c}\text { Signaling } \\
\text { Pathway/Protein }\end{array}$ & Pre-Treatment & $\begin{array}{l}\text { NO/iNOS/eNOS } \\
\text { Level }\end{array}$ & Result & Ref. \\
\hline & & eNOS phosphorylation & & $\mathrm{NO} \downarrow$ & $\begin{array}{l}\text { Tumor } \\
\text { metastasis }\end{array}$ & \\
\hline Lung cancer & & $\begin{array}{l}\text { Decreasing activity and } \\
\text { phosphorylation of eNOS }\end{array}$ & $\begin{array}{l}4 \mathrm{~T} 1 \text { cancer cell } \\
\text { inoculation }\end{array}$ & $\mathrm{NO} \downarrow$ & Metastasis & \\
\hline Breast cancer & $\begin{array}{l}\text { MDA-MB- } 231 \text { breast } \\
\text { cancer cells }\end{array}$ & Akt phosphorylation & TIMP-1 silencing & $\mathrm{NO} \uparrow$ & $\begin{array}{l}\text { Tumor cell } \\
\text { growth and } \\
\text { proliferation }\end{array}$ & [20] \\
\hline Breast cancer & $\begin{array}{l}\text { MDA-MB- } 468 \text { breast } \\
\text { cancer cells }\end{array}$ & $\begin{array}{c}\text { S-nitrosylation of Ras, } \\
\text { Ets-1, MAPK }\end{array}$ & - & $\mathrm{NO} \uparrow$ & $\begin{array}{l}\text { Tumor } \\
\text { metastasis }\end{array}$ & [21] \\
\hline Breast cancer & $\begin{array}{c}\text { The murine cell line } \\
66 \text { CL4, human breast } \\
\text { cancer cell line MCF-7, } \\
\text { human triple negative } \\
\text { breast cancer (TNBC) } \\
\text { cell lines }\end{array}$ & $\begin{array}{l}\text { VEGF, phosphorylation of } \\
\gamma \text {-H2AX foci and RAD51 } \\
\text { foci }\end{array}$ & Glucocorticoids & $\mathrm{NO} \uparrow$ & Angiogenesis & [23] \\
\hline Breast cancer & $\begin{array}{l}\text { Human breast cancer } \\
\text { cell lines MDA-MB-468, } \\
\text { ZR 75-30 and } \\
\text { MDA-MB-231 }\end{array}$ & $\begin{array}{c}\text { Dephosphorylation of } \\
\text { ERK and Akt }\end{array}$ & $\begin{array}{l}\text { Sodium } \\
\text { orthovanadate } \\
\text { and antisense } \\
\text { oligonucleotides }\end{array}$ & $\mathrm{NO} \uparrow$ & $\begin{array}{l}\text { Cancer cell } \\
\text { growth }\end{array}$ & [24] \\
\hline Breast cancer & $\begin{array}{l}\text { Human breast cancer } \\
\text { cell lines MDA-MB-231, } \\
\text { MCF-7, and } \\
\text { MDA-MB-468 }\end{array}$ & $\begin{array}{l}\text { Raf/MEK/ERK and PI-3 } \\
\text { kinase/Akt pathways }\end{array}$ & $\begin{array}{l}\text { diethylenetriamine- } \\
\text { NONOate } \\
\text { (DETA- } \\
\text { NONOate) }\end{array}$ & $\mathrm{NO} \uparrow$ & $\begin{array}{l}\text { Proliferation of } \\
\text { cancer cell }\end{array}$ & [25] \\
\hline Lung cancer & $\begin{array}{l}\text { C10 and E10 cells, LM1 } \\
\text { and LM2 cells }\end{array}$ & $\begin{array}{l}\text { ERK1/2 kinase } \\
\text { phosphorylation }\end{array}$ & $\begin{array}{l}\text { ERK } 1 / 2 \text { kinase } \\
\text { inhibitor U0126 }\end{array}$ & $\mathrm{NO} \uparrow$ & $\begin{array}{l}\text { Tumor } \\
\text { proliferation } \\
\text { and growth }\end{array}$ & [27] \\
\hline Lung cancer & $\begin{array}{c}\text { Human colon } \\
\text { carcinoma cell line and } \\
\text { human lung } \\
\text { adenocarcinoma cell } \\
\text { line }\end{array}$ & $\begin{array}{l}\text { Tyrosine phosphorylation } \\
\text { and p53 gene } \\
\text { accumulation }\end{array}$ & $\begin{array}{l}\text { Retroviral vector } \\
\text { DFG-iNOS }\end{array}$ & $\mathrm{NO} \uparrow \mathrm{NOS} \uparrow$ & Metastasis & [28] \\
\hline Lung cancer & Bronchiolar Clara cells & $\begin{array}{l}\text { Vascular endothelial } \\
\text { growth factor }\end{array}$ & iNOS - & $\mathrm{NO} \uparrow \mathrm{iNOS} \uparrow$ & Angiogenesis & [29] \\
\hline Lung cancer & $\begin{array}{l}\text { NCI-H157 } \\
\text { and NCI-H522 }\end{array}$ & $\begin{array}{l}\text { Tyrosine phosphorylation } \\
\text { and MMP expression }\end{array}$ & - & $\mathrm{NO} \uparrow \mathrm{NOS} \uparrow$ & Angiogenesis & [30] \\
\hline Lung cancer & $\begin{array}{c}\text { Human non-small lung } \\
\text { cancer } \\
\text { (NSCLC)-derived cell } \\
\text { line H460, H23, and } \\
\text { H292 }\end{array}$ & Akt phosphorylation & - & $\mathrm{NO} \uparrow$ & $\begin{array}{l}\text { Promote cancer } \\
\text { stem cell }\end{array}$ & [31] \\
\hline Lung cancer & NCI-H460 cells & $\begin{array}{l}\text { Inhibition the } \\
\text { ubiquitination of Bcl-2 } \\
\text { protein }\end{array}$ & $\begin{array}{l}\text { Sodium } \\
\text { nitroprusside, } \\
\text { dipropylenetri- } \\
\text { amine NONOate } \\
\text { and cisplatin }\end{array}$ & $\mathrm{NO} \uparrow$ & $\begin{array}{c}\text { increase cell } \\
\text { death resistance }\end{array}$ & [33] \\
\hline Ovarian cancer & $\begin{array}{l}\text { SKOV-3 and OVCAR-3 } \\
\text { cell lines }\end{array}$ & $\begin{array}{c}\downarrow \text { Phosphorylation of } \\
\text { STAT3, Akt }\end{array}$ & $\begin{array}{l}\text { Spermine nitric } \\
\text { oxide complex } \\
\text { hydrate } \\
\text { (SPER/NO), di- } \\
\text { ethylenetriamine } \\
\text { nitric oxide } \\
\text { adduct } \\
\text { (DETA/NO) }\end{array}$ & $\mathrm{NO} \uparrow$ & $\begin{array}{l}\text { Cancer cell } \\
\text { apoptosis }\end{array}$ & [54] \\
\hline Ovarian cancer & $\begin{array}{l}\text { SKOV-3 and OVCAR-3 } \\
\text { cell lines }\end{array}$ & $\begin{array}{c}\uparrow \text { Phosphorylation of } \\
\text { STAT3 }\end{array}$ & $\begin{array}{l}\text { Arctigenin, } \\
\text { S-nitroso-N- } \\
\text { acetylpenicillamine } \\
\text { (SNAP) } \\
\text { High }\end{array}$ & $\mathrm{NO} \uparrow$ & $\begin{array}{l}\text { Inhibit } \\
\text { arctigenin- } \\
\text { induced cell } \\
\text { apoptosis }\end{array}$ & [55] \\
\hline Ovarian caner & $\begin{array}{l}\text { SKOV-3 and OVCAR-3 } \\
\text { cell lines }\end{array}$ & $\begin{array}{c}\uparrow \text { Phosphorylation of } \\
\text { p38MAPK, } \\
\downarrow \text { expression of survivin }\end{array}$ & $\begin{array}{l}\text { concentration of } \\
\text { NO donors (SNP, } \\
\text { SNAP) or } \\
\text { overexpression of } \\
\text { iNOS }\end{array}$ & $\mathrm{NO} \uparrow$ & $\begin{array}{l}\text { Cancer cell } \\
\text { apoptosis }\end{array}$ & [57] \\
\hline & - & $\begin{array}{c}\uparrow \text { Activation of } \\
\text { PI3K/Akt/survivin } \\
\text { signaling pathway }\end{array}$ & $\begin{array}{c}\text { Low } \\
\text { concentration of } \\
\text { NO donors (SNP, } \\
\text { SNAP) or ectopic } \\
\text { expression of low } \\
\text { amounts of iNOS }\end{array}$ & $\mathrm{NO} \uparrow$ & Cytoprotection & \\
\hline
\end{tabular}


Table A1. Cont.

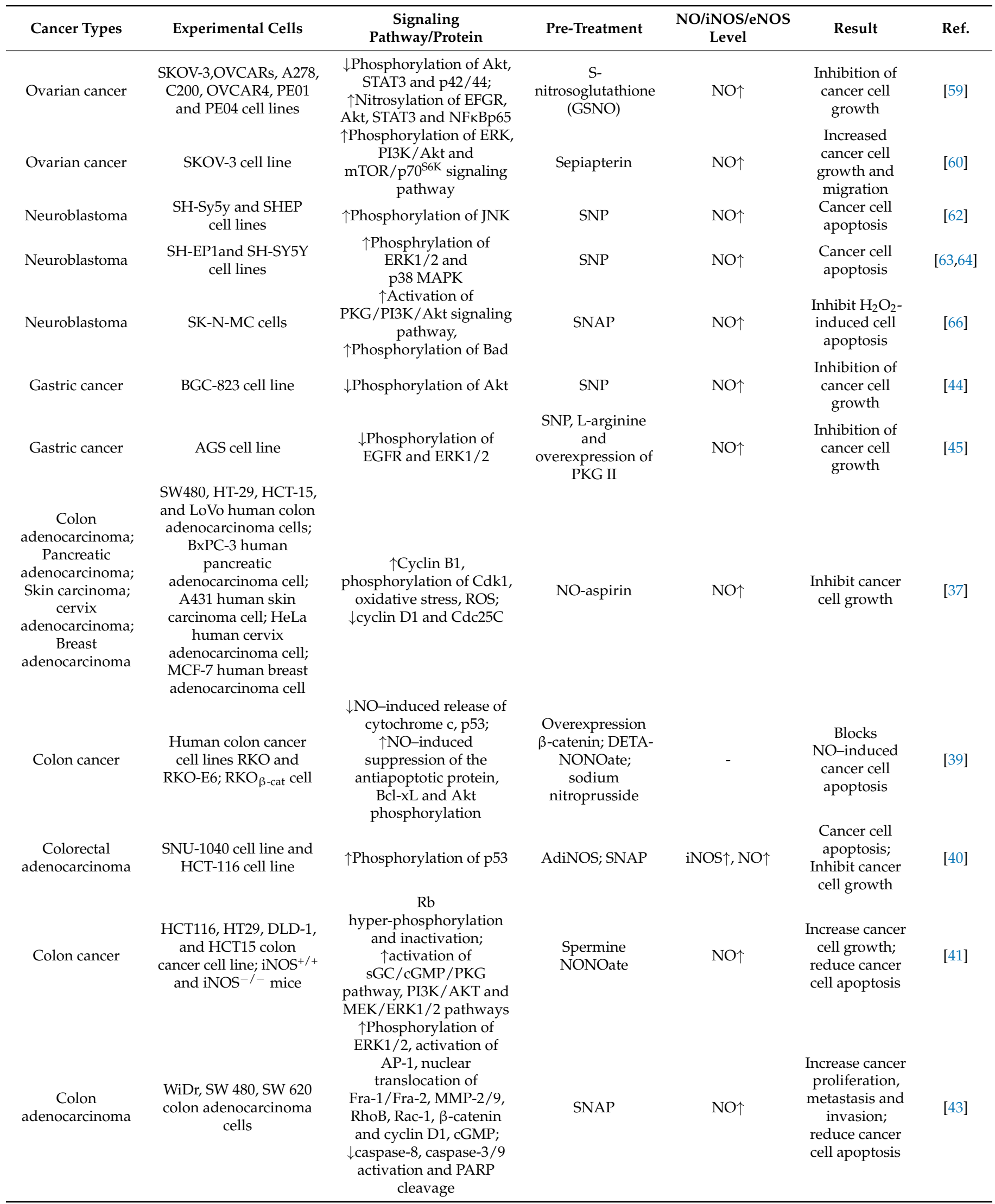


Table A1. Cont.

\begin{tabular}{|c|c|c|c|c|c|c|}
\hline Cancer Types & Experimental Cells & $\begin{array}{c}\text { Signaling } \\
\text { Pathway/Protein }\end{array}$ & Pre-Treatment & $\begin{array}{c}\text { NO/iNOS/eNOS } \\
\text { Level }\end{array}$ & Result & Ref. \\
\hline $\begin{array}{l}\text { Pancreatic ductal } \\
\text { adenocarcinoma }\end{array}$ & $\begin{array}{c}\text { LSL-Kras G12D; } \\
\text { LSL-Trp53 }^{\mathrm{R} 172 \mathrm{H} /+} ; \\
\text { Pdx-1-Cre (KPC) } \\
\text { pancreatic cancer mouse } \\
\text { model and } \\
\text { NOS2-deficient KPC } \\
\text { (NKPC) mice; primary } \\
\text { pancreatic tumor tissue }\end{array}$ & $\begin{array}{c}\downarrow \text { Phosphorylation of } \\
\text { FOXO, activation of ERK } \\
\text { and PI3K/AKT signaling } \\
\text { pathway; }\end{array}$ & iNOS deficiency & iNOS $\downarrow$ NO $\downarrow$ & $\begin{array}{l}\text { Decrease cancer } \\
\text { cell growth; } \\
\text { cancer cell } \\
\text { apoptosis }\end{array}$ & [46] \\
\hline \multirow[t]{2}{*}{ Pancreatic cancer } & $\begin{array}{l}\text { Seventy-two pancreatic } \\
\text { adenocarcinoma tissue } \\
\text { specimens }\end{array}$ & $\uparrow$ iNOS-induced NO & - & - & $\begin{array}{l}\text { Cancer cell } \\
\text { apoptosis }\end{array}$ & [48] \\
\hline & & $\uparrow \mathrm{COX}-2$ activate NF-кB & & & $\begin{array}{l}\text { Reduce cancer } \\
\text { cell apoptosis }\end{array}$ & \\
\hline $\begin{array}{l}\text { Pancreatic ductal } \\
\text { adenocarcinoma }\end{array}$ & $\begin{array}{l}\text { MiaPaCa II, AsPC-1, } \\
\text { and 293T cells; } \\
\text { four-week-old } \\
\text { SCID-beige mice; } \\
\text { Balb/c NU } \backslash \text { NU mice }\end{array}$ & $\begin{array}{c}\uparrow N O, \text { PP2A; } \downarrow \text { MEK/ERK } \\
\text { pathway, recruitment of } \\
\text { phosphorylated c-Jun, } \\
\text { integrin } \beta 4 \text { expression, } \\
\text { ITGB } 4\end{array}$ & Netrin-1 & $\mathrm{NO} \uparrow$ & $\begin{array}{l}\text { Cancer cell } \\
\text { apoptosis; } \\
\text { inhibit cancer } \\
\text { cell growth }\end{array}$ & [49] \\
\hline Pancreatic Cancer & $\begin{array}{l}\text { MIAPaCa-2, Panc-1, } \\
\text { MCF-7, MB 468, and } \\
\text { HepG2 cells }\end{array}$ & $\begin{array}{c}\downarrow \text { Phosphorylation of } \\
\text { insulin receptor/IGF-I } \\
\text { receptor, IRS-1, IGF-I } \\
\text { receptor, Akt/PKB, } \\
\text { GSK-3 } \beta \text {; } \\
\uparrow \text { phosphorylation of } \\
\text { ERK-1/2 }\end{array}$ & $\begin{array}{c}\text { SNAP, GSNO, } \\
1400 W\end{array}$ & $\mathrm{NO} \uparrow$ & $\begin{array}{l}\text { Inhibit cancer } \\
\text { proliferation } \\
\text { and invasion }\end{array}$ & [51] \\
\hline $\begin{array}{l}\text { BPH, low- and } \\
\text { high-grade PIN } \\
\text { and prostatic } \\
\text { carcinoma }\end{array}$ & $\begin{array}{c}\text { Tissue samples } \\
\text { of BPH, low-grade PIN, } \\
\text { high-grade PIN } \\
\text { and primary prostatic } \\
\text { adenocarcinomas }\end{array}$ & $\uparrow$ iNOS, iNOS-induced NO & - & $\begin{array}{c}\mathrm{NO} \uparrow \\
\mathrm{iNOS} \uparrow\end{array}$ & $\begin{array}{l}\text { Induce cancer } \\
\text { cell metastasis } \\
\text { and } \\
\text { tumorigenesis }\end{array}$ & {$[36]$} \\
\hline Prostate cancer & $\begin{array}{l}\text { PC-3 prostate cancer } \\
\text { cell line }\end{array}$ & $\begin{array}{c}\downarrow \text { Activity of HRE } \\
\text { promoter, Akt } \\
\text { phosphorylation; inhibit } \\
\text { HIF-1 } \alpha \text { translation }\end{array}$ & NO-sulindac & $\mathrm{NO} \uparrow$ & $\begin{array}{l}\text { Inhibit cancer } \\
\text { cell growth and } \\
\text { invasion; } \\
\text { Cancer cell } \\
\text { apoptosis }\end{array}$ & [34] \\
\hline
\end{tabular}

\section{References}

1. Liu, Y.; Beyer, A.; Aebersold, R. On the Dependency of Cellular Protein Levels on mRNA Abundance. Cell 2016, 165, 535-550. [CrossRef]

2. Pieroni, L.; Iavarone, F.; Olianas, A.; Greco, V.; Desiderio, C.; Martelli, C.; Manconi, B.; Sanna, M.T.; Messana, I.; Castagnola, M.; et al. Enrichments of post-translational modifications in proteomic studies. J. Sep. Sci. 2020, 43, 313-336. [CrossRef]

3. Humphrey, S.; James, D.E.; Mann, M. Protein Phosphorylation: A Major Switch Mechanism for Metabolic Regulation. Trends Endocrinol. Metab. 2015, 26, 676-687. [CrossRef]

4. Arrington, J.V.; Hsu, C.-C.; Elder, S.G.; Tao, W.A. Recent advances in phosphoproteomics and application to neurological diseases. Analyst 2017, 142, 4373-4387. [CrossRef]

5. Singh, V.; Ram, M.; Kumar, R.; Prasad, R.; Roy, B.K.; Singh, K.K. Phosphorylation: Implications in Cancer. Protein J. 2017, 36, 1-6. [CrossRef]

6. Crane, B.R.; Arvai, A.S.; Ghosh, D.K.; Wu, C.; Getzoff, E.D.; Stuehr, D.J.; Tainer, J.A. Structure of nitric oxide synthase oxygenase dimer with pterin and substrate. Science 1998, 279, 2121-2126. [CrossRef]

7. Kamm, A.; Przychodzen, P.; Kuban-Jankowska, A.; Jacewicz, D.; Dabrowska, A.M.; Nussberger, S.; Wozniak, M.; GorskaPonikowska, M. Nitric oxide and its derivatives in the cancer battlefield. Nitric Oxide 2019, 93, 102-114. [CrossRef] [PubMed]

8. Crowell, A.J.; Steele, E.V.; Sigman, C.C.; Fay, J.R. Is inducible nitric oxide synthase a target for chemoprevention? Mol. Cancer Ther. 2003, 2, 815-823. [PubMed]

9. Fukumura, D.; Kashiwagi, S.; Jain, R.K. The role of nitric oxide in tumor progression. Nat. Rev. Cancer 2006, 6, 521-534. [CrossRef] [PubMed]

10. Vannini, F.; Kashfi, K.; Nath, N. The dual role of iNOS in cancer. Redox Biol. 2015, 6, 334-343. [CrossRef] [PubMed]

11. Kashfi, K. Nitric oxide in cancer and beyond. Biochem. Pharmacol. 2020, 176, 114006. [CrossRef]

12. Fukumura, D.; Jain, R.K. Role of nitric oxide in angiogenesis and microcirculation in tumors. Cancer Metastasis Rev. 1998, 17, 77-89. [CrossRef]

13. Alimoradi, H.; Greish, K.; Gamble, A.B.; Giles, G.I. Controlled Delivery of Nitric Oxide for Cancer Therapy. Pharm. Nanotechnol. 2019, 7, 279-303. [CrossRef] 
14. Hundley, T.R.; Rigas, B. Nitric Oxide-Donating Aspirin Inhibits Colon Cancer Cell Growth via Mitogen-Activated Protein Kinase Activation. J. Pharmacol. Exp. Ther. 2005, 316, 25-34. [CrossRef]

15. Narayanankutty, A. PI3K/ Akt/ mTOR Pathway as a Therapeutic Target for Colorectal Cancer: A Review of Preclinical and Clinical Evidence. Curr. Drug Targets 2019, 20, 1217-1226. [CrossRef] [PubMed]

16. Mishra, D.; Patel, V.; Banerjee, D. Nitric Oxide and S-Nitrosylation in Cancers: Emphasis on Breast Cancer. Breast Cancer: Basic Clin. Res. 2020, 14. [CrossRef]

17. Basudhar, D.; Somasundaram, V.; de Oliveira, G.A.; Kesarwala, A.; Heinecke, J.L.; Cheng, R.Y.; Glynn, S.A.; Ambs, S.; Wink, D.A.; Ridnour, L.A. Nitric Oxide Synthase-2-Derived Nitric Oxide Drives Multiple Pathways of Breast Cancer Progression. Antioxidants Redox Signal. 2017, 26, 1044-1058. [CrossRef] [PubMed]

18. Sen, S.; Kawahara, B.; Chaudhuri, G. Mitochondrial-associated nitric oxide synthase activity inhibits cytochrome c oxidase: Im-plications for breast cancer. Free Radic. Biol. Med. 2013, 57, 210-220. [CrossRef] [PubMed]

19. Smeda, M.; Kieronska, A.; Adamski, M.G.; Proniewski, B.; Sternak, M.; Mohaissen, T.; Przyborowski, K.; Derszniak, K.; Kaczor, D.; Stojak, M.; et al. Nitric oxide deficiency and endothelial-mesenchymal transition of pulmonary endothelium in the progression of 4T1 metastatic breast cancer in mice. Breast Cancer Res. 2018, 20, 1-15. [CrossRef] [PubMed]

20. Ridnour, L.A.; Barasch, K.M.; Windhausen, A.N.; Dorsey, T.H.; Lizardo, M.M.; Yfantis, H.G.; Lee, N.H.; Switzer, C.H.; Cheng, R.Y.S.; Heinecke, J.L.; et al. Nitric Oxide Synthase and Breast Cancer: Role of TIMP-1 in NO-mediated Akt Activation. PLoS ONE 2012, 7, e44081. [CrossRef]

21. Marshall, E.H.; Foster, M.W. S-nitrosylation of Ras in breast cancer. Breast Cancer Res. 2012, 14, 1-2. [CrossRef]

22. Monteiro, H.P.; Rodrigues, E.G.; Reis, A.K.A.; Longo, L.S.; Ogata, F.T.; Moretti, A.I.; da Costa, P.E.; Teodoro, A.C.; Toledo, M.S.; Stern, A. Nitric oxide and interactions with reactive oxygen species in the development of melanoma, breast, and colon cancer: A redox signaling perspective. Nitric Oxide 2019, 89, 1-13. [CrossRef] [PubMed]

23. Flaherty, R.L.; Intabli, H.; Falcinelli, M.; Bucca, G.; Hesketh, A.; Patel, B.A.; Allen, M.; Smith, C.; Flint, M.S. Stress hormonemediated acceleration of breast cancer metastasis is halted by inhibition of nitric oxide synthase. Cancer Lett. 2019, 459, 59-71. [CrossRef] [PubMed]

24. Pervin, S.; Singh, R.; Freije, A.W.; Chaudhuri, G. MKP-1-induced dephosphorylation of extracellular signal-regulated kinase is essential for triggering nitric oxide-induced apoptosis in human breast cancer cell lines: Implications in breast cancer. Cancer Res. 2003, 63, 8853-8860. [PubMed]

25. Pervin, S.; Singh, R.; Hernandez, E.; Wu, G.; Chaudhuri, G. Nitric Oxide in Physiologic Concentrations Targets the Translational Machinery to Increase the Proliferation of Human Breast Cancer Cells: Involvement of Mammalian Target of Rapamycin/eIF4E Pathway. Cancer Res. 2007, 67, 289-299. [CrossRef] [PubMed]

26. Tyagi, A.; Singh, R.P.; Ramasamy, K.; Raina, K.; Redente, E.F.; Dwyer-Nield, L.D.; Radcliffe, R.A.; Malkinson, A.M.; Agarwal, R. Growth inhibition and regression of lung tumors by silibinin: Modulation of angiogenesis by macrophage-associated cytokines and nuclear factor-kappaB and signal transducers and activators of transcription 3. Cancer Prev. Res. 2009, 2, 74-83. [CrossRef] [PubMed]

27. Rice, P.L.; Barrett, B.S.; Fritz, J.M.; Srebernak, M.C.; Kisley, L.R.; Malkinson, A.M.; Dwyer-Nield, L.D. Regulation of cytokineinduced prostanoid and nitric oxide synthesis by extracellular signal-regulated kinase 1/2 in lung epithelial cells. Exp. Lung Res. 2010, 36, 558-571. [CrossRef]

28. Forrester, K.; Ambs, S.; Lupold, S.E.; Kapust, R.B.; Spillare, E.A.; Weinberg, W.C.; Felley-Bosco, E.; Wang, X.W.; Geller, D.A.; Tzeng, E.; et al. Nitric oxide-induced p53 accumulation and regulation of inducible nitric oxide synthase expression by wild-type p53. Proc. Natl. Acad. Sci. USA 1996, 93, 2442-2447. [CrossRef]

29. Kisley, L.R.; Barrett, B.S.; Bauer, A.K.; Dwyer-Nield, L.D.; Barthel, B.; Meyer, A.M.; Thompson, D.C.; Malkinson, A.M. Genetic ablation of inducible nitric oxide synthase decreases mouse lung tumorigenesis. Cancer Res. 2002, 62, 6850-6856.

30. Phillips, P.G.; Birnby, L.M.; Narendran, A.; Milonovich, W.L. Nitric oxide modulates capillary formation at the endothelial cell-tumor cell interface. Am. J. Physiol. Cell. Mol. Physiol. 2001, 281, L278-L290. [CrossRef]

31. Maiuthed, A.; Bhummaphan, N.; Luanpitpong, S.; Mutirangura, A.; Aporntewan, C.; Meeprasert, A.; Rungrotmongkol, T.; Rojanasakul, Y.; Chanvorachote, P. Nitric oxide promotes cancer cell dedifferentiation by disrupting an Oct4:caveolin-1 complex: A new regulatory mechanism for cancer stem cell formation. J. Biol. Chem. 2018, 293, 13534-13552. [CrossRef]

32. Tyryshkin, A.; Gorgun, F.; Fattah, E.A.; Mazumdar, T.; Pandit, L.; Zeng, S.; Eissa, N. Src Kinase-mediated Phosphorylation Stabilizes Inducible Nitric-oxide Synthase in Normal Cells and Cancer Cells. J. Biol. Chem. 2010, 285, 784-792. [CrossRef]

33. Chanvorachote, P.; Nimmannit, U.; Stehlik, C.; Wang, L.; Jiang, B.-H.; Ongpipatanakul, B.; Rojanasakul, Y. Nitric Oxide Regulates Cell Sensitivity to Cisplatin-Induced Apoptosis through S-Nitrosylation and Inhibition of Bcl-2 Ubiquitination. Cancer Res. 2006, 66, 6353-6360. [CrossRef]

34. Stewart, G.D.; Nanda, J.; Brown, D.J.; Riddick, A.C.; Ross, J.A.; Habib, F.K. NO-sulindac inhibits the hypoxia response of PC-3 prostate cancer cells via the Akt signalling pathway. Int. J. Cancer 2009, 124, 223-232. [CrossRef]

35. Semenza, G.L. Targeting HIF-1 for cancer therapy. Nat. Rev. Cancer 2003, 3, 721-732. [CrossRef] [PubMed]

36. Baltaci, S.; Orhan, D.; Gögüs, Ç.; Türkölmez, K.; Tulunay, Ö.; Gögüs, O. Inducible nitric oxide synthase expression in benign prostatic hyperplasia, low- and high-grade prostatic intraepithelial neoplasia and prostatic carcinoma. BJU Int. 2001, 88, 100-103. [CrossRef] [PubMed] 
37. Gao, L.; Williams, J.L. Abstract 3817: Nitric oxide-donating aspirin induces G2/M phase cell cycle arrest in human cancer cells by regulating phase transition proteins. Exp. Mol. Ther. 2012, 72, 3817. [CrossRef]

38. Menon, S.G.; Goswami, P.C. A redox cycle within the cell cycle: Ring in the old with the new. Oncogene 2006, 26, 1101-1109. [CrossRef] [PubMed]

39. Wang, H.; MacNaughton, W.K. Overexpressed beta-catenin blocks nitric oxide-induced apoptosis in colonic cancer cells. Cancer Res. 2005, 65, 8604-8607. [CrossRef] [PubMed]

40. Cook, T.; Wang, Z.; Alber, S.; Liu, K.; Watkins, S.C.; Vodovotz, Y.; Billiar, T.R.; Blumberg, D. Nitric oxide and ionizing radiation syner-gistically promote apoptosis and growth inhibition of cancer by activating p53. Cancer Res. 2004, 64, 8015-8021. [CrossRef]

41. Stern, A.; Costa, P.; Monteiro, H.; Reis, A. Nitric oxide: Protein tyrosine phosphorylation and protein S-nitrosylation in cancer. Biomed. J. 2015, 38, 380. [CrossRef]

42. Ying, L.; Hofseth, A.B.; Browning, D.D.; Nagarkatti, M.; Nagarkatti, P.S.; Hofseth, L.J. Nitric Oxide Inactivates the Retinoblastoma Pathway in Chronic Inflammation. Cancer Res. 2007, 67, 9286-9293. [CrossRef]

43. Babykutty, S.; Suboj, P.; Srinivas, P.; Nair, A.S.; Chandramohan, K.; Gopala, S. Insidious role of nitric oxide in migration/invasion of colon cancer cells by upregulating MMP-2/9 via activation of cGMP-PKG-ERK signaling pathways. Clin. Exp. Metastasis 2012, 29, 471-472. [CrossRef] [PubMed]

44. Sang, J.; Chen, Y.; Tao, Y. Nitric oxide inhibits gastric cancer cell growth through the modulation of the Akt pathway. Mol. Med. Rep. 2011, 4, 1163-1167. [CrossRef] [PubMed]

45. Yao, X.; Wu, Y.; Zhu, M.; Qian, H.; Chen, Y. Nitric oxide/cyclic guanosine monophosphate inducers sodium nitroprusside and L-arginine inhibit the proliferation of gastric cancer cells via the activation of type II cyclic guanosine monophos-phate-dependent protein kinase. Oncol. Lett. 2015, 10, 479-484. [CrossRef] [PubMed]

46. Wang, J.; He, P.; Gaida, M.; Yang, S.; Schetter, A.J.; Gaedcke, J.; Ghadimi, B.M.; Ried, T.; Yfantis, H.; Lee, D.; et al. Inducible nitric oxide synthase enhances disease aggressiveness in pancreatic cancer. Oncotarget 2016, 7, 52993-53004. [CrossRef] [PubMed]

47. Paik, J.H.; Kollipara, R.; Chu, G.; Ji, H.; Xiao, Y.; Ding, Z.; Miao, L.; Tothova, Z.; Horner, J.W.; Carrasco, D.R.; et al. FoxOs are lineage-restricted redundant tumor suppressors and regulate endothelial cell homeostasis. Cell 2007, 128, 309-323. [CrossRef]

48. Kong, G.; Kim, E.K.; Kim, W.S.; Lee, K.T.; Lee, Y.W.; Lee, J.K.; Paik, S.W.; Rhee, J.C. Role of cyclooxygenase-2 and inducible nitric oxide synthase in pancreatic cancer. J. Gastroenterol. Hepatol. 2002, 17, 914-921. [CrossRef] [PubMed]

49. An, X.-Z.; Zhao, Z.-G.; Luo, Y.; Zhang, R.; Tang, X.-Q.; Hao, D.-L.; Zhao, X.; Lv, X.; Liu, D.-P. Netrin-1 suppresses the MEK/ERK pathway and ITGB4 in pancreatic cancer. Oncotarget 2016, 7, 24719-24733. [CrossRef]

50. Bergmann, U.; Funatomi, H.; Kornmann, M.; Beger, H.G.; Korc, M. Increased Expression of Insulin Receptor Substrate-1 in Human Pancreatic Cancer. Biochem. Biophys. Res. Commun. 1996, 220, 886-890. [CrossRef]

51. Sugita, H.; Kaneki, M.; Furuhashi, S.; Hirota, M.; Takamori, H.; Baba, H. Nitric oxide inhibits the proliferation and invasion of pan-creatic cancer cells through degradation of insulin receptor substrate-1 protein. Mol. Cancer Res. 2010, 8, 1152-1163. [CrossRef] [PubMed]

52. Stewart, C.; Ralyea, C.; Lockwood, S. Ovarian Cancer: An Integrated Review. Semin. Oncol. Nurs. 2019, 35, 151-156. [CrossRef] [PubMed]

53. Wang, Y.; Shen, Y.; Wang, S.; Shen, Q.; Zhou, X. The role of STAT3 in leading the crosstalk between human cancers and the immune system. Cancer Lett. 2018, 415, 117-128. [CrossRef] [PubMed]

54. Kielbik, M.; Klink, M.; Brzezinska, M.; Szulc, I.; Sulowska, Z. Nitric oxide donors: Spermine/NO and diethylenetriamine/NO induce ovarian cancer cell death and affect STAT3 and AKT signaling proteins. Nitric Oxide 2013, 35, 93-109. [CrossRef] [PubMed]

55. Huang, K.; Li, L.A.; Meng, Y.G.; You, Y.Q.; Fu, X.Y.; Song, L. Arctigenin promotes apoptosis in ovarian cancer cells via the iN-OS/NO/STAT3/survivin signalling. Basic Clin. Pharmacol. Toxicol. 2014, 115, 507-511. [CrossRef]

56. Ferrandina, G.; Legge, F.; Martinelli, E.; Ranelletti, O.F.; Zannoni, G.F.; Lauriola, L.; Gessi, M.; Gallotta, V.; Scambia, G. Survivin expression in ovarian cancer and its correlation with clinico-pathological, surgical and apoptosis-related parameters. Br. J. Cancer 2005, 92, 271-277. [CrossRef]

57. Engels, K.; Knauer, S.K.; Loibl, S.; Fetz, V.; Harter, P.; Schweitzer, A.; Fisseler-Eckhoff, A.; Kommoss, F.; Hanker, L.; Nekljudova, V.; et al. NO Signaling Confers Cytoprotectivity through the Survivin Network in Ovarian Carcinomas. Cancer Res. 2008, 68, 5159-5166. [CrossRef] [PubMed]

58. Fraser, M.; Chan, S.L.; Chan, S.S.L.; Fiscus, R.R.; Tsang, B.K. Regulation of p53 and suppression of apoptosis by the soluble guanylyl cyclase/cGMP pathway in human ovarian cancer cells. Oncogene 2005, 25, 2203-2212. [CrossRef] [PubMed]

59. Gir, S.; Rattan, R.; Deshpande, M.; Maguire, J.L.; Johnson, Z.; Graham, R.P.; Shridhar, V. Preclinical therapeutic potential of a nitro-sylating agent in the treatment of ovarian cancer. PLOS ONE 2014, 9, e97897.

60. Choi, S.W.; Cho, Y.-R.; Kim, S.H.; Ko, H.Y.; Kim, M.-D.; Seo, D.-W. Sepiapterin inhibits cell proliferation and migration of ovarian cancer cells via down-regulation of p70S6K-dependent VEGFR-2 expression. Oncol. Rep. 2011, 26, 861-867. [CrossRef]

61. Behrens, A.; Sibilia, M.; Wagner, E.F. Amino-terminal phosphorylation of c-Jun regulates stress-induced apoptosis and cellular proliferation. Nat. Genet. 1999, 21, 326-329. [CrossRef] [PubMed]

62. Li, L.; Feng, Z.; Porter, A.G. JNK-dependent Phosphorylation of c-Jun on Serine 63 Mediates Nitric Oxide-induced Apoptosis of Neuroblastoma Cells. J. Biol. Chem. 2004, 279, 4058-4065. [CrossRef] [PubMed] 
63. Chen, S.; Guo, D.; Zhang, W.; Xie, Y.; Yang, H.; Cheng, B.; Wang, L.; Yang, R.; Bi, J.; Feng, Z. Biglycan, a Nitric OxideDownregulated Proteoglycan, Prevents Nitric Oxide-Induced Neuronal Cell Apoptosis via Targeting Erk1/2 and p38 Signaling Pathways. J. Mol. Neurosci. 2018, 66, 68-76. [CrossRef] [PubMed]

64. Nashida, T.; Takuma, K.; Fukuda, S.; Kawasaki, T.; Takahashi, T.; Baba, A.; Ago, Y.; Matsuda, T. The specific Na+/Ca2+ exchange inhibitor SEA0400 prevents nitric oxide-induced cytotoxicity in SH-SY5Y cells. Neurochem. Int. 2011, 59, 51-58. [CrossRef] [PubMed]

65. Ha, K.S.; Kim, K.M.; Kwon, Y.G.; Bai, S.K.; Nam, W.D.; Yoo, Y.M.; Kim, P.K.; Chung, H.T.; Billiar, T.R.; Kim, Y.M. Nitric oxide prevents 6-hydroxydopamine-induced apoptosis in PC12 cells through cGMP-dependent PI3 kinase/Akt activation. FASEB J. 2003, 17, 1036-1047. [CrossRef]

66. Yoo, Y.M.; Jung, E.M.; Ahn, C.; Jeung, E.B. Nitric oxide prevents H2O2-induced apoptosis in SK-N-MC human neuroblastoma cells. Int. J. Biol. Sci. 2018, 14, 1974-1984. [CrossRef] [PubMed]

67. Chang, C.-F.; Diers, A.R.; Hogg, N. Cancer cell metabolism and the modulating effects of nitric oxide. Free. Radic. Biol. Med. 2015, 79, 324-336. [CrossRef] [PubMed]

68. Choudhari, S.K.; Chaudhary, M.; Bagde, S.; Gadbail, A.R.; Joshi, V. Nitric oxide and cancer: A review. World J. Surg. Oncol. 2013, 11, 118. [CrossRef]

69. Yasuda, H. Solid tumor physiology and hypoxia-induced chemo/radio-resistance: Novel strategy for cancer therapy: Nitric oxide donor as a therapeutic enhancer. Nitric Oxide 2008, 19, 205-216. [CrossRef]

70. Kang, Y.; Kim, J.; Park, J.; Lee, Y.M.; Saravanakumar, G.; Park, K.M.; Choi, W.; Kim, K.; Lee, E.; Kim, C.; et al. Tumor vasodilation by $\mathrm{N}$-Heterocyclic carbene-based nitric oxide delivery triggered by high-intensity focused ultrasound and enhanced drug homing to tumor sites for anti-cancer therapy. Biomaterials 2019, 217, 119297. [CrossRef]

71. Huerta, S. Nitric oxide for cancer therapy. Futur. Sci. OA 2015, 1, 44. [CrossRef]

72. Frederiksen, L.J.; Sullivan, R.; Maxwell, L.R.; MacDonald-Goodfellow, S.K.; Adams, M.A.; Bennett, B.M.; Siemens, D.R.; Graham, C.H. Chemosensitization of Cancer In vitro and In vivo by Nitric Oxide Signaling. Clin. Cancer Res. 2007, 13, 2199-2206. [CrossRef] [PubMed]

73. Zhao, X.; Cai, A.; Peng, Z.; Liang, W.; Xi, H.; Li, P.; Chen, G.; Yu, J.; Chen, L. JS-K induces reactive oxygen species-dependent anti-cancer effects by targeting mitochondria respiratory chain complexes in gastric cancer. J. Cell. Mol. Med. 2019, 23, 2489-2504. [CrossRef] [PubMed]

74. Ishima, Y.; Inoue, A.; Fang, J.; Kinoshita, R.; Ikeda, M.; Watanabe, H.; Maeda, H.; Otagiri, M.; Maruyama, T. Poly-S-nitrosated human albumin enhances the antitumor and antimetastasis effect of bevacizumab, partly by inhibiting autophagy through the gen-eration of nitric oxide. Cancer Sci. 2015, 106, 194-200. [CrossRef]

75. Wang, L.; Chang, Y.; Feng, Y.; Li, X.; Cheng, Y.; Jian, H.; Ma, X.; Zheng, R.; Wu, X.; Xu, K.; et al. Nitric Oxide Stimulated Programmable Drug Release of Nanosystem for Multidrug Resistance Cancer Therapy. Nano Lett. 2019, 19, 6800-6811. [CrossRef] [PubMed]

76. Li, S.; Song, X.; Zhu, W.; Chen, Y.; Zhu, R.; Wang, L.; Chen, X.; Song, J.; Yang, H. Light-Switchable Yolk-Mesoporous Shell UCNPs@MgSiO3 for Nitric Oxide-Evoked Multidrug Resistance Reversal in Cancer Therapy. ACS Appl. Mater. Interfaces 2020, 12, 30066-30076. [CrossRef]

77. Chegaev, K.; Fraix, A.; Gazzano, E.; Abd-Ellatef, G.E.F.; Blangetti, M.; Rolando, B.; Conoci, S.; Riganti, C.; Fruttero, R.; Gasco, A.; et al. Light-Regulated NO Release as a Novel Strategy to Overcome Doxorubicin Multidrug Resistance. ACS Med. Chem. Lett. 2017, 8, 361-365. [CrossRef] [PubMed]

78. Kim, J.; Yung, B.; Kim, W.J.; Chen, X. Combination of nitric oxide and drug delivery systems: Tools for overcoming drug resistance in chemotherapy. J. Control. Release 2017, 263, 223-230. [CrossRef] 